\title{
PREDIKSI POLA PENJUALAN TIKET KAPAL PT. PELNI CABANG MAKASSAR MENGGUNAKAN METODE ALGORITMA APRIORI
}

\author{
Arif Firmansyah'; ${ }^{1}$ Nita Merlina ${ }^{2 *}$ \\ *corresponding author \\ Sistem Informasi, STMIK Nusa Mandiri \\ Jakarta, Indonesia \\ arif.firmansyah08@gmail.com ${ }^{1}$; nita@nusamandiri.ac.id ${ }^{2 *}$
}

\begin{abstract}
The availability of tickets for passengers is one of the most important factors in the business of transporting passenger ship transportation services. In undergoing its business process, the problem that occurs at PT Pelayaran Nasional Indonesia Branches is the depletion of the stock of ticket blanks, especially during peak season, whereas when the Branch requires the ticket blanks, ticket blank distribution experiences obstacles in the expedition section which is an external factor that cannot be directly controlled. The purpose of this study is to predict ship ticket sales which are often done by looking at the pattern of previous ticket purchases. The method used in this study uses Algortima Apriori, in this case the writer takes the Makassar Branch case study. The Apriori algorithm produces rules for associations between items in January 2018 until December 2018, it is known that the pattern of ship ticket sales that if you buy KM Lambelu tickets, you will buy KM Bukit Siguntang tickets simultaneously with a support value of $75 \%$ and a confidence value of $90 \%$. Keywords: Apriori Algorithm, Data Mining, Ship Ticket Sales.
\end{abstract}

Intisari-Ketersediaan tiket untuk penumpang merupakan salah satu faktor yang sangat penting dalam bidang usaha transportasi jasa angkutan kapal penumpang. Dalam menjalani proses bisnisnya, masalah yang terjadi di Cabang-Cabang PT Pelayaran Nasional Indonesia adalah menipisnya stok blanko tiket terutama pada masa peak season, sedangkan ketika Cabang membutuhkan blanko tiket tersebut, distribusi blanko tiket mengalami hambatan di bagian ekspedisi yang merupakan faktor eksternal yang tidak bisa dikontrol secara langsung. Tujuan dari penelitian ini adalah untuk memprediksikan penjualan tiket kapal laut yang sering dilakukan dengan melihat pola pembelian tiket sebelumnya. Metode yang digunakan dalam penelitian ini menggunakan Algortima Apriori, dalam hal ini penulis mengambil studi kasus Cabang Makassar. Algoritma Apriori menghasilkan aturan asosiasi antar item pada bulan Januari 2018 sampai dengan Desember 2018 diketahui pola penjualan tiket kapal bahwa jika membeli tiket KM Lambelu maka akan membeli tiket KM Bukit Siguntang secara bersamaan dengan nilai support $75 \%$ dan nilai confidence $90 \%$.

Katakunci: Algoritma Apriori, Data Mining, Penjualan Tiket Kapal.

\section{PENDAHULUAN}

PT Pelayaran Nasional Indonesia adalah perusahaan pelayaran nasional yang menyediakan jasa transportasi laut, meliputi jasa angkutan penumpang, dan muatan barang antar pulau. Ditahun 2019 ini perusahaan mengoperasikan 26 armada kapal penumpang yang diklasifikasi berdasarkan kapasitas jumlah penumpang, diantaranya : Kapal tipe 3.000 pax, tipe 2.000 pax, tipe 1.000 pax, tipe 500 pax, tipe Ro-Ro (Roll on Roll off) dan 1 unit kapal ferry cepat dengan kapasitas seluruhnya berjumlah 36.913 penumpang, 46 kapal perintis, 6 kapal barang tol laut dan 1 kapal ternak. Dalam melaksanakan tanggung jawabnya tidak hanya terbatas melayani rute komersial, tetapi juga melayani pelayaran dengan rute pulau-pulau kecil terluar. Saat ini kapal PT Pelayaran Nasional Indonesia menyinggahi 95 pelabuhan kapal penumpang dan lebih dari 300 pelabuhan kapal perintis dengan 46 kantor Cabang dan dilayani di 400 travel agen yang tersebar di seluruh Indonesia.

Salah satu Cabang PT Pelayaran Nasional Indonesia yang paling ramai penumpang adalah Pelabuhan Makassar yang berada di Sulawesi Selatan. Kapal-kapal penumpang milik PT. Pelayaran Nasional Indonesia yang melalui Pelabuhan Makassar pada tahun 2018 diantaranya adalah KFC Jetliner, KM Binaiya, KM Bukit Siguntang, KM Ciremai, KM Dobonsolo, KM Dorolonda, KM Gunung Dempo, KM Lambelu, KM Leuser, KM Nggapulu, KM Pangrango, KM Sinabung, KM Sirimau, KM Tidar, KM Tatamailau, KM Tilongkabila, KM Umsini, dan KM Wilis. 
Permasalahan yang terjadi di Cabang-Cabang PT Pelayaran Nasional Indonesia adalah menipisnya stok blanko tiket terutama pada masa peak season, sedangkan ketika Cabang membutuhkan blanko tiket tersebut, distribusi blanko tiket mengalami hambatan di bagian ekspedisi yang merupakan faktor eksternal yang tidak bisa dikontrol secara langsung. Jumlah pengiriman blanko tiket dari Kantor Pusat ke Cabang selama ini hanya mengikuti permintaan dari Cabang berdasarkan data penjualan.

Dengan adanya kegiatan penjualan setiap hari, data semakin lama akan semakin bertambah banyak (Pormes, R., \& Manongga, 2017). Data tersebut tidak hanya berfungsi sebagai arsip Perusahaan, data tersebut dapat dimanfaatkan dan diolah menjadi informasi yang berguna untuk strategi pemasaran Perusahaan.

Untuk menjaga ketersediaan blanko tiket di Cabang PT Pelayaran Nasional Indonesia, penulis mencoba menggunakan salah satu teknik dalam pengolahan data penjualan tiket dengan menggunakan Algoritma Apriori, dalam hal ini penulis mengambil studi kasus Cabang Makassar.

Proses pencarian asosiasi atau hubungan antar item data ini di ambil dari suatu basis data relasional (Rezkiani, 2016). Penerapan algorima apriori membantu dalam membentuk kandidat kombinasi item, kemudian dilakukan pengujian kombinasi untuk menentukan parameter support dan confidence minimum yang memenuhi persyaratan. Parameter support dan confidence minimum merupakan nilai ambang yang di berikan oleh pengguna.

Tujuan dari penelitian ini adalah untuk memprediksikan penjualan tiket kapal laut yang sering dilakukan dengan melihat pola pembelian tiket sebelumnya , sehingga dengan adanya infromasi terkait dapat mengantisipasi terjadinya ketidak tersediaan tiket khususnya di perusahaan PT . PELNI cabang Makasar. Beberapa penelitian terkait dengan ketersediaan tiket sudah pernah ada namun di dominasi dengan penelitian ketersediaan tiket pesawat terbang, sedangkan unt tiket kapal laut masih belum banyak yang meneliti.

\section{BAHAN DAN METODE}

Tahap-tahap tersebut bersifat interaktif di mana pemakai terlibat langsung atau dengan perantaraan knowledge base. Tahap-tahap ini diilustrasikan sebagai berikut:

1. Pembersihan data (untuk membuang data yang tidak konsisten dan noise)

2. Integrasi data (penggabungan data dari beberapa sumber)

3. Transformasi data (data diubah menjadi bentuk yang sesuai untuk di-mining)
4. Aplikasi teknik DM

5. Evaluasi pola yang ditemukan (untuk menemukan yang menarik/bernilai)

6. Presentasi pengetahuan (dengan teknik visualisasi).

(Surmayanti, Marfalino, \& Rahmi, 2015) Scalability, yaitu besarnya ukuran basis data yang digunakan.

1. Dimensionality, yaitu banyaknya jumlah atribut dalam data yang akan diproses.

2. Complex and Heterogeneous Data, yaitu data yang kompleks dan mempunyai variasi yang beragam.

3. Data Quality, kualitas data yang akan diproses seperti data yang bersih dari noise, missing value, dan sebagainya.

4. Data Ownership and Distribution, yaitu siapa yang memiliki data dan bagaimana distribusinya.

5. Privacy Preservation, yaitu menjaga kerahasiaan data yang banyak diterapkan pada data nasabah perbankan.

6. Streaming Data, yaitu aliran data itu sendiri.

Algoritma Apriori merupakan algoritma dasar yang diusulkan oleh Agrawal \& Srikant pada tahun 1994 yang bertujuan untuk menentukan frequent itemsets untuk aturan asosiasi boolean. (Siregar, 2014) . Algoritma apriori termasuk jenis aturan asosiasi pada data mining. Aturan yang menyatakan asosiasi antara beberapa atribut sering disebut affinity analysis atau market basket analysis. Analisis asosiasi atau association rule mining adalah teknik data mining untuk menemukan aturan suatu kombinasi item. Salah satu tahap analisis asosiasi yang menarik perhatian banyak peneliti untuk menghasilkan algoritma yang efisien adalah analisis pola frequensi tinggi (frequent pattern mining). Penting tidaknya suatu asosiasi dapat diketahui dengan dua tolak ukur, yaitu : support dan confidence. Support (nilai penunjang) adalah persentase kombinasi item tersebut dalam database, sedangkan confidence (nilai kepastian) adalah kuatnya hubungan antaritem dalam aturan asosiasi.

(Putria, 2018) Proses utama yang dilakukan dalam algoritma apriori untuk mendapat frequent itemset, yaitu :

1. Join (penggabungan)

Proses ini dilakukan dengan cara pengkombinasian item dengan yang item lainnya hingga tidak bisa terbentuk kombinasi lagi.

2. Prune (pemangkasan)

Proses pemangkasan yaitu hasil dari item yang telah dikombinasikan kemudian 
dipangkas dengan menggunakan minimum support yang telah ditentukan.

(Yakun, 2018) Metodologi dasar analisis asosiasi terbagi menjadi 2 tahap sebagai berikut:

a. Analisis Pola Frekuensi Tinggi

Tahap ini mencari kombinasi antar item yang memenuhi syarat minimum dari nilai support dalam database. Nilai support diperoleh dengan rumus :

Support $(A)=\frac{\Sigma \text { Transaksi yang mengandung } \mathrm{A}}{\Sigma \text { Transaksi }} * 100 \%$

Sementara nilai support dari 2 item diperoleh dari rumus :

Support $(\mathrm{A}, \mathrm{B})=\mathrm{P}(\mathrm{A} \cap \mathrm{B})$

Support $(A, B)=\frac{\Sigma \text { Transaksi yang mengandung } \mathrm{A}, \mathrm{B}}{\Sigma \text { Transaksi }} * 100 \%$

b. Pembentukan Aturan Asosiasi

Setelah semua pola frekuensi tertinggi ditemukan, barulah dicari aturan asosiasi yang memenuhi syarat minimum confidence dengan menghitung confidence aturan asosiatif $\mathrm{A} \rightarrow \mathrm{B}$. Nilai confidence aturan $\mathrm{A} \rightarrow \mathrm{B}$ diperoleh rumus berikut:

Confidence $=P(A / B=$

$\frac{\Sigma \text { Transaksi yang mengandung A dan B }}{\Sigma \text { Transaksi A }} * 100 \%$

Dalam tahap metodologi penelitian ini menggunakan tahapan penelitian yang sistematis untuk membantu penelitian menjadi terarah dengan baik. Berikut adalah metodologi penelitian yang dilakukan penulis.

1. Studi Awal

Langkah awal dari penelitian ini adalah dengan mencari dan mempelajari masalah yang ada pada di PT. Pelayaran Nasional Indonesia. Kemudian menentukan ruang lingkup masalah, latar belakang masalah, dan mempelajari beberapa literatur yang berkaitan dengan permasalahan dan bagaimana mencari solusi dari masalah tersebut.

2. Pengumpulan Data

Penulis melakukan wawancara, observasi dan dokumentasi di PT. Pelayaran Nasional Indonesia. Untuk mengetahui informasi yang dibutuhkan peneliti melakukan pengumpulan data laporan penjualan periode January 2018 - Desember 2018 di PT. Pelayaran Nasional Indonesia.

3. Pengolahan Data dengan Data Mining

Pada tahap pengolahan data terlebih dahulu melakukan identifikasi masalah yang ada di PT. Pelayaran Nasional Indonesia. Tahap selanjutnya dilakukan analisa masalah dengan mengamati data laporan penjualan agar penulis mengetahui dan memperoleh gambaran yang jelas bagaimana bentuk penyelesaian dan algoritma apa yang dapat digunakan untuk penyelesaiannya. Kemudian penulis menggunakan teknik data mining dengan algoritma Apriori untuk mendapatkan hasil sebagai tujuan yang akan dicapai oleh peneliti dengan menghitung dua pola sebagai berikut:

a. Pada pola perhitungan algoritma apriori akan mencari nilai itemset yaitu nilai support dan nilai confidance.

b. Pada pola perhitungan dengan aplikasi Tanagra, data yang akan di input adalah bentuk tabular dari total keseluruhan penjualan yang masuk penjualan tiga besar, maka akan menghasilkan rule nilai sebagai pembanding dari perhitungan manual algoritma apriori yang kemudian dapat dijadikan pihak PT Pelayaran Nasional Indonesia sebagai pengetahuan dalam menjaga ketersediaan stok tiket di tiap cabang.

4. Analisis Hasil

Penulis melakukan analisis hasil dengan menggunakan Tanagra 1.4 atau aplikasi data mining serta algoritma apriori untuk menguhubungkan dengan database yang telah diisi atau data-data yang akan diuji.

Penelitian dilakukan di PT. Pelayaran Nasional Indonesia cabang Makassar pada jumlah penumpang tiap kapal yaitu dengan menghitung dua variable yaitu nilai support $30 \%$ dan confidence $60 \%$. Dalam menganalisa data penulis menggunakan perhitungan algoritma apriori.

\section{HASIL DAN PEMBAHASAN}

Berdasarkan data penjualan tiket kapal penumpang PT. Pelayaran Nasional Indonesia cabang Makassar selama 1 tahun dengan periode January 2018 - Desember 2018 didapatkan pola transaksi dengan menganalisis 3 kapal yang paling banyak tiket yang terjual setiap bulannya. dapat dilihat pada Tabel 1 :

Tabel 1. Pola Transaksi Penjualan Tiket Kapal Penumpang

\begin{tabular}{clll}
\hline Bulan & \multicolumn{4}{c}{ Itemset } \\
\hline 1 & $\begin{array}{l}\text { KM Lambelu, KM Bukit Siguntang, KM } \\
\text { Gunung Dempo }\end{array}$ \\
\hline 2 & $\begin{array}{l}\text { KM Bukit Siguntang, KM Gunung Dempo, } \\
\text { KM Tidar }\end{array}$ \\
\hline 3 & $\begin{array}{l}\text { KM Lambelu, KM Tilongkabila, KM } \\
\text { Nggapulu }\end{array}$ \\
\hline 4 & $\begin{array}{l}\text { KM Bukit Siguntang,KM Lambelu, KM } \\
\text { Tilongkabila }\end{array}$ \\
\hline
\end{tabular}


VOL. 5. NO. 2 FEBRUARI 2020

P-ISSN: 2685-8223 | E-ISSN: 2527-4864

\begin{tabular}{cl}
\hline Bulan & \multicolumn{1}{c}{ Itemset } \\
\hline 5 & $\begin{array}{l}\text { KM Lambelu, KM Tilongkabila, KM Bukit } \\
\text { Siguntang }\end{array}$ \\
\hline 6 & $\begin{array}{l}\text { KM Tilongkabila, KM Bukit Siguntang, KM } \\
\text { Dorolonda }\end{array}$ \\
\hline 7 & $\begin{array}{l}\text { KM Bukit Siguntang, KM Lambelu, KM } \\
\text { Gunung Dempo }\end{array}$ \\
\hline 8 & $\begin{array}{l}\text { KM Bukit Siguntang, KM Lambelu, KM } \\
\text { Binaiya }\end{array}$ \\
\hline 9 & $\begin{array}{l}\text { KM Bukit Siguntang, KM Lambelu, KM } \\
\text { Tilongkabila }\end{array}$ \\
\hline 10 & $\begin{array}{l}\text { KM Lambelu, KM Tilongkabila, KM Bukit } \\
\text { Siguntang }\end{array}$ \\
\hline 11 & $\begin{array}{l}\text { KM Bukit Siguntang, KM Lambelu, KM } \\
\text { Nggapulu }\end{array}$ \\
\hline 12 & $\begin{array}{l}\text { KM Lambelu,KM Bukit Siguntang, KM } \\
\text { Tilongkabila }\end{array}$ \\
\hline Sumber : (PT. PELNI, 2019)
\end{tabular}

Sumber : (PT. PELNI, 2019)

Format Tabular data transaksi bulanan, bila dibentuk akan tampak seperti pada tabel 2 :

Tabel 2. Format Tabular Data Transaksi

\begin{tabular}{|c|c|c|c|c|c|c|c|c|}
\hline $\begin{array}{c}\text { Bul } \\
\text { an }\end{array}$ & $\begin{array}{c}\text { KM. } \\
\text { Bina } \\
\text { iya }\end{array}$ & $\begin{array}{c}\text { KM. } \\
\text { Bukit } \\
\text { Sigun } \\
\text { tang }\end{array}$ & $\begin{array}{c}\text { KM. } \\
\text { Dorol } \\
\text { onda }\end{array}$ & $\begin{array}{c}\text { KM. } \\
\text { Gun } \\
\text { ung } \\
\text { Dem } \\
\text { po }\end{array}$ & $\begin{array}{l}\text { KM. } \\
\text { Lam } \\
\text { belu }\end{array}$ & $\begin{array}{l}\text { KM. } \\
\text { Ngga } \\
\text { pulu }\end{array}$ & $\begin{array}{c}\text { KM } \\
\text { Tid } \\
\text { ar }\end{array}$ & $\begin{array}{c}\text { KM. } \\
\text { Tilongk } \\
\text { abila }\end{array}$ \\
\hline 1 & 0 & 1 & 0 & 1 & 1 & 0 & 0 & 0 \\
\hline 2 & 0 & 1 & 0 & 1 & 0 & 0 & 1 & 0 \\
\hline 3 & 0 & 0 & 0 & 0 & 1 & 1 & 0 & 1 \\
\hline 4 & 0 & 1 & 0 & 0 & 1 & 0 & 0 & 1 \\
\hline 5 & 0 & 1 & 0 & 0 & 1 & 0 & 0 & 1 \\
\hline 6 & 0 & 1 & 1 & 0 & 0 & 0 & 0 & 1 \\
\hline 7 & 0 & 1 & 0 & 1 & 1 & 0 & 0 & 0 \\
\hline 8 & 1 & 1 & 0 & 0 & 1 & 0 & 0 & 0 \\
\hline 9 & 0 & 1 & 0 & 0 & 1 & 0 & 0 & 1 \\
\hline 10 & 0 & 1 & 0 & 0 & 1 & 0 & 0 & 1 \\
\hline 11 & 0 & 1 & 0 & 0 & 1 & 1 & 0 & 0 \\
\hline 12 & 0 & 1 & 0 & 0 & 1 & 0 & 0 & 1 \\
\hline
\end{tabular}

Sumber : (Firmansyah \& Merlina, 2019)

\section{Analisa Pola Frekuensi Tinggi}

1. Pembentukan 1 Itemset

Proses pembentukan $\mathrm{C} 1$ atau disebut dengan 1 itemset dengan jumlah minimum support $=30 \%$. Berikut merupakan perhitungan pembentukan 1 itemset :

Support (KM Binaiya)

$=\frac{\Sigma \text { Transaksi KM Binaiya }}{\Sigma 12}=\frac{1}{12} * 100 \%=8,33 \%$

Support (KM Bukit Siguntang)

$=\frac{\Sigma \text { Transaksi KM Bukit Siguntang }}{\Sigma 12}=\frac{11}{12} * 100 \%=91,67 \%$

Support (KM Dorolonda)

$=\frac{\Sigma \text { Transaksi KM Dorolonda }}{\Sigma 12}=\frac{1}{12} * 100 \%=8,33 \%$

Support (KM Gunung Dempo)
$=\frac{\Sigma \text { Transaksi KM Gunung Dempo }}{\Sigma 12}=\frac{3}{12} * 100 \%=25 \%$

Support (KM Lambelu)

$=\frac{\Sigma \text { Transaksi KM Lambelu }}{\Sigma 12}=\frac{10}{12} * 100 \%=83,33 \%$

Support (KM Nggapulu)

$=\frac{\Sigma \text { Transaksi KM Nggapulu }}{\Sigma 12}=\frac{2}{12} * 100 \%=16,67 \%$

Support (KM Tidar)

(7)

$=\frac{\Sigma \text { Transaksi KM Tidar }}{\Sigma 12}=\frac{1}{12} * 100 \%=8,33 \%$

Support (KM Tilongkabila)

$=\frac{\Sigma \text { Transaksi KM Tilongkabila }}{\Sigma 12}=\frac{7}{12} * 100 \%=58,33 \%$

Minimal Support yang ditentukan adalah 30\%, dari perhitungan diatas itemset dengan hasil yang tidak memenuhi minimal Support akan dihilangkan, terlihat seperti tabel 3:

Tabel 3. Support Dari Tiap Itemset

\begin{tabular}{|c|c|c|}
\hline Itemset & Jumlah & Support \\
\hline KM. Bukit Siguntang & 11 & $91,67 \%$ \\
\hline KM. Lambelu & 10 & $83,33 \%$ \\
\hline KM. Tilongkabila & 7 & $58,33 \%$ \\
\hline \multicolumn{3}{|c|}{ Sumber : (Firmansyah \& Merlina, 2019) } \\
\hline \multicolumn{3}{|c|}{$\begin{array}{l}\text { Proses selanjutnya adalah pembentukan C2 } \\
\text { u disebut dengan } 2 \text { itemset dengan jumlah } \\
\text { himum support }=30 \% \text {. Berikut merupakan } \\
\text { hitungan pembentukan C2 atau } 2 \text { itemset: }\end{array}$} \\
\hline \multicolumn{3}{|c|}{$\begin{array}{l}\text { Support (KM Bukit Siguntang, KM Lambelu) } \\
= \\
\Sigma \text { Transaksi KM Bukit Siguntang dan KM Lambelu }\end{array}$} \\
\hline$\frac{\Sigma \text { Transaksi KM Bukit Sigunt }}{\Sigma 12}$ & KM Lambelt & \\
\hline
\end{tabular}

Support (KM Bukit Siguntang, KM Tilongkabila)

$\frac{\Sigma \text { Transaksi KM Bukit Siguntang, KM Tilongkabila }}{\Sigma 12}=\frac{6}{12} * 100 \%=50 \%$

Support (KM Lambelu, KM Tilongkabila)

$\frac{\Sigma \text { Transaksi KM Lambelu dan KM Tilongkabila }}{\Sigma 12}=\frac{6}{12} * 100 \%=50 \%$

Tabel 4. Support kombinasi 2 Itemset

\begin{tabular}{lcc} 
Itemset & Jumlah & Support \\
\hline $\begin{array}{l}\text { KM. Bukit Siguntang, } \\
\text { KM Lambelu }\end{array}$ & 9 & $75 \%$ \\
\hline $\begin{array}{l}\text { KM Bukit Siguntang, } \\
\text { KM Tilongkabila }\end{array}$ & 6 & $50 \%$ \\
$\begin{array}{l}\text { KM Lambelu, KM. } \\
\text { Tilongkabila }\end{array}$ & 6 & $50 \%$ \\
\hline
\end{tabular}


Sumber : (Firmansyah \& Merlina, 2019)

Proses selanjutnya adalah pembentukan C3 atau disebut dengan 3 itemset dengan jumlah minimum support $=30 \%$. Berikut merupakan perhitungan pembentukan $\mathrm{C} 3$ atau 3 itemset:

Support (KM Bukit Siguntang, KM Lambelu, KM Tilongkabila)

$=\frac{\sum \text { Transaksi KM Bukit Siguntang,KM Lambelu,KM Tilongkabila }}{\Sigma 12}$

$=\frac{5}{12} * 100 \%=41,67 \%$

Tabel 5. Support kombinasi 3 Itemset

\begin{tabular}{|c|c|c|}
\hline Itemset & Jumlah & Support \\
\hline $\begin{array}{l}\text { KM. Bukit Siguntang, } \\
\text { KM Lambelu, KM } \\
\text { Tilongkabila }\end{array}$ & 5 & $41,67 \%$ \\
\hline
\end{tabular}

Setelah semua pola frekuensi tinggi ditemukan, baru dicari aturan asosiasi yang memenuhi syarat minimum Confidence dengan menghitung Confidence aturan asosiatif $\mathrm{A} \rightarrow \mathrm{B}$. Minimal Confidence $=60 \%$. Berikut merupakan perhitungan Confidence :

Confidence $=P($ KM Bukit Siguntang $/$ KM Lambelu $)$ $=\frac{\Sigma \text { Transaksi KM Bukit Siguntang dan KM Lambelu }}{\Sigma \text { Transal }}$

$=\frac{9}{11} * 100 \%=81,82 \%$

Confidence $=P(K M$ Lambelu $/ K M$ Bukit Siguntang $)$ $=\underline{\Sigma \text { Transaksi KM Lambelu dan KM Bukit Siguntang }}$

$=\frac{9}{10} * 100 \%=90 \%$

Confidence $=\quad P(K M \quad$ Bukit Siguntang $/ K M$ Tilongkabila)

$=\frac{\sum \text { Transaksi KM Bukit Siguntang dan KM Tilongkabila }}{\sum \text { Transaksi KM Bukit Siguntang }}$

$=\frac{6}{11} * 100 \%=54,55 \%$

Confidence $=P($ KM Tilongkabila $/$ KM Bukit

Siguntang)

$=\frac{\Sigma \text { Transaksi KM Tilongkabila dan KM Bukit Siguntang }}{\Sigma \text { Transaki KM Tilongkabla }}$

$=\frac{6}{7} * 100 \%=85,71 \%$

Confidence $=P($ KM Lambelu $/ K M$ Tilongkabila $)$ $=\Sigma$ Transaksi KM Lambelu dan KM Tilongkabila

$=\frac{6}{10} * 100 \%=60 \%$
Confidence $=P($ KM Tilongkabila $/$ KM Lambelu $)$

$=\frac{\Sigma \text { Transaksi KM Tilongkabila dan KM Lambelu }}{\Sigma \text { Transa }}$

$=\frac{6}{7} * 100 \%=85,71 \%$

Confidence $=\quad P(K M \quad$ Bukit Siguntang $/ K M$

Tilongkabila/KM Lambelu)

$=\underline{\Sigma \text { Transaksi KM Bukit Siguntang, KM Tilongkabila dan KM Lambelu }}$

$=\frac{5}{11} * 100 \%=45,45 \%$

Confidence $=P(K M \quad$ Tilongkabilal KM Bukit Siguntang/KM Lambelu)

$=\underline{\Sigma \text { Transaksi KM Tilongkabila, KM Bukit Siguntang dan KM Lambelu }}$

$=\frac{5}{7} * 100 \%=71,43 \%$

Confidence $=P($ KM Lambelu $/ K M$ Bukit Siguntang $/ K M$ Tilongkabila)

$=\underline{\Sigma \text { Transaksi KM Lambelu, KM Bukit Siguntang dan KM Tilongkabila }}$

$=\frac{5}{10} * 100 \%=50 \%$

Confidence $=P($ KM Bukit Siguntang $/$ KM Lambelu $/ K M$ Tilongkabila)

$=\frac{\Sigma \text { Transaksi KM Bukit Siguntang dan KM Lambelu, KM Tilongkabila }}{\Sigma}$

$=\frac{\Sigma \text { Transaksi KM Bukit Siguntang dan KM Lambelu }}{5}$

$=\frac{5}{9} * 100 \%=55,56 \%$

Confidence $=\quad P(K M \quad$ Bukit Siguntang $/ K M$ Tilongkabila/KM Lambelu)

$=\frac{\Sigma \text { Transaksi KM Bukit Siguntang dan KM Tilongkabila, KM Lambelu }}{\Sigma \text { Transaksi KM Bukit Siguntang dan KM Tilongkabia }}$

$=\frac{5}{6} * 100 \%=83,33 \%$

Confidence $=P(K M$ Tilongkabila $/$ KM Lambelu $/ K M$ Bukit Siguntang)

$\Sigma$ Transaksi KM Tilongkabila dan KM Lambelu, KM Bukit Siguntang

$=\frac{5}{6} * 100 \%=83,33 \%$

Dari kombinasi 2 kombinasi itemset dan 3 kombinasi itemset dapat dilihat besarnya nilai support, dan confidence dari aturan asosiasi final seperti tampak pada Tabel 6 .

Tabel 6.Aturan Asosiasi Final

\begin{tabular}{|c|c|c|}
\hline Aturan & Support & Confidence \\
\hline Jika membeli tiket & & \\
\hline $\begin{array}{l}\text { KM Bukit Siguntang } \\
\text { maka akan membeli }\end{array}$ & $75 \%$ & $81,82 \%$ \\
\hline
\end{tabular}

Tiket KM Lambelu 
VOL. 5. NO. 2 FEBRUARI 2020

P-ISSN: 2685-8223 | E-ISSN: 2527-4864

\begin{tabular}{|c|c|c|}
\hline Aturan & Support & Confidence \\
\hline Jika membeli Tiket & & \\
\hline $\begin{array}{l}\text { KM Lambelu maka } \\
\text { akan membeli tiket } \\
\text { KM Bukit Siguntang }\end{array}$ & $75 \%$ & $90,00 \%$ \\
\hline
\end{tabular}

Jika membeli tiket

KM Lambelu maka akan membeli Tiket KM Tilongkabila

Jika membeli tiket

KM Tilongkabila

maka akan membeli

tiket KM Bukit

$50 \% \quad 85,71 \%$

Siguntang

\begin{tabular}{|c|c|c|}
\hline \multicolumn{3}{|l|}{ Jika membeli tiket } \\
\hline KM Tilongkabila & & \\
\hline $\begin{array}{l}\text { maka akan membeli } \\
\text { tiket KM Lambelu }\end{array}$ & $50 \%$ & $85,71 \%$ \\
\hline
\end{tabular}

\begin{tabular}{lr}
\hline Jika & membeli Tiket \\
KM Tilongkabila
\end{tabular}

maka akan membeli

tiket KM Bukit

Siguntang dan tiket

$41,67 \%$

$71,43 \%$

KM Lambelu

Jika membeli tiket

KM Bukit Siguntang

dan Tiket KM

Tilongkabila maka

$41,67 \%$

$83,33 \%$

akan membeli tiket

KM Lambelu

Jika membeli tiket

KM Lambelu dan

Tiket KM

Tilongkabila maka

akan membeli tiket

$41,67 \% \quad 83,33 \%$

KM Bukit Siguntang

Sumber : (Firmansyah \& Merlina, 2019)

(Badrul, 2016) Penerapan algoritma Apriori yang dilakukan melalui perangkat lunak terbukti menujukkan hasil yang sama dibandingkan dengan melakukan perhitungan secara manual

Algoritma Apriori pada Tanagra dapat terbentuk dengan algoritma atau langkah-langkah yang telah ditentukan. Algoritma ini terdiri dari dua algoritma yaitu:

1. Algoritma Support

Algoritma penentuan Support dapat dilihat pada gambar 2 . Berikut hasil Support dari hasil analis yang penulis lakukan

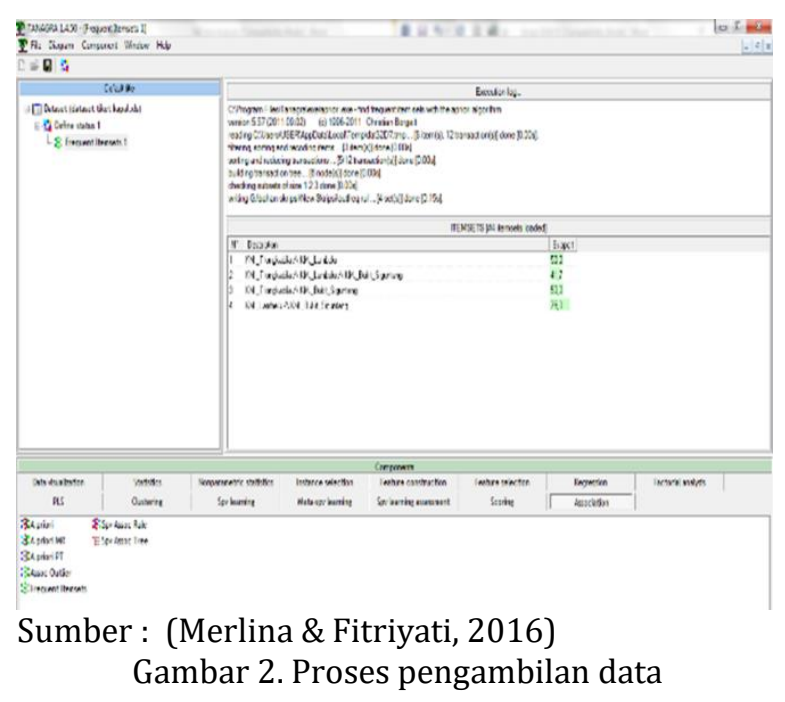

Gambar 2 diatas menggambarkan suatu proses pengambilan data, dan menampilkan hasil prosesnya.

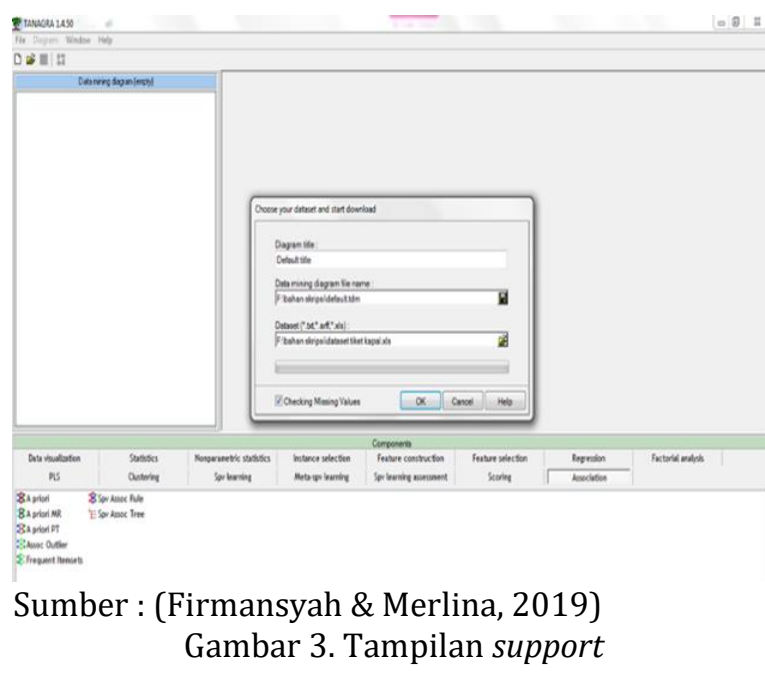

2. Algoritma Confidence

Algoritma penentuan Confidence dapat dilihat pada gambar 4 . Berikut hasil dari penerapan menggunakan Tanagra.

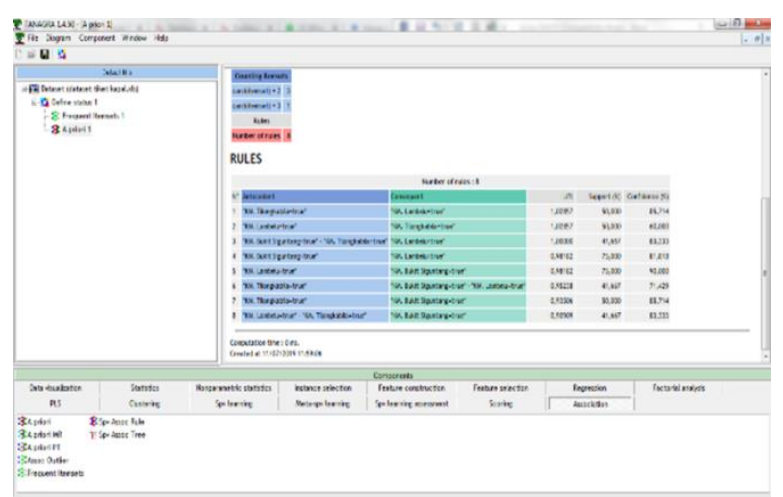

Sumber : (Firmansyah \& Merlina, 2019)

Gambar 4. Algoritma Confidence 


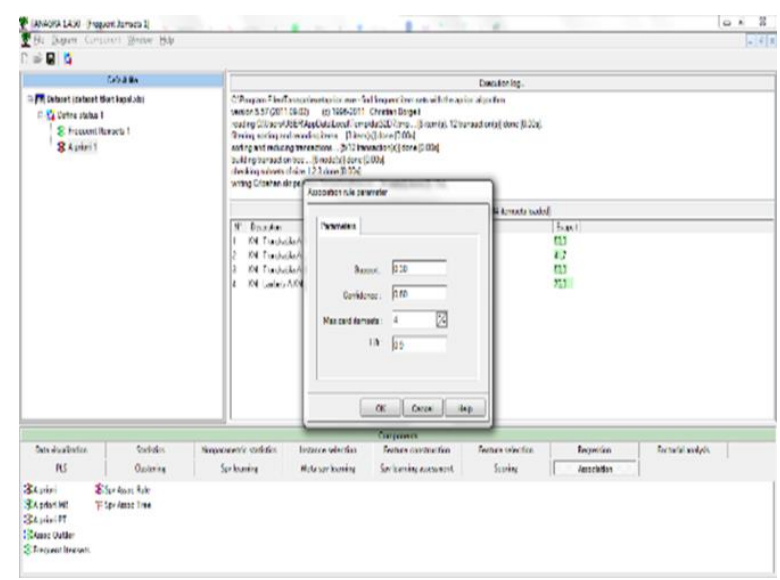

Sumber : (Firmansyah \& Merlina, 2019) Gambar 5. Hasil Algoritma Confidence

Gambar 5 diatas menampilkan hasil Prediksi Pola Penjualan Tiket Kapal PT. PELNI Cabang Makassar menggunakan algoritma Confidence.

\section{KESIMPULAN}

Berdasarkan pembahasan yang telah dilakukan dengan metode asosiasi dan algoritma apriori serta dilakukanya pengujian dan simulasi dengan aplikasi Tanagra maka penulis menarik beberapa kesimpulan yang penting, metode algoritma apriori dapat simpulkan pola penjualan tiket kapal PT Pelayaran Nasional Indonesia cabang Makassar pada bulan January - Desember 2018 selama 1 tahun dengan nilai support dan nilai confindence tertinggi adalah jika membeli tiket KM Lambelu maka akan membeli tiket KM Bukit Siguntang secara bersamaan dengan nilai support $75 \%$ dan nilai confidence $90 \%$. Algoritma apriori dapat membantu mengembangkan strategi pemasaran untuk memasarkan kapal yang lain, dengan meneliti apa kelebihan kapal yang paling banyak tiket terjual serta dapat menjaga ketersediaan stok blanko tiket di cabang Makassar.

\section{REFERENSI}

Badrul, M. (2016). Algoritma Asosiasi Dengan Algoritma Apriori Untuk Analisa Data Penjualan. PILAR, 12(2), 121-129. Retrieved from

http://ejournal.nusamandiri.ac.id/index.php /pilar/article/view/266

Firmansyah, A., \& Merlina, N. (2019). Laporan akhir penelitian: Prediksi Pola Penjualan Tiket Kapal PT. PELNI Cabang Makassar Menggunakan Metode Algoritma Apriori. Jakarta.
Merlina, N., \& Fitriyati, N. H. (2016). Sistem Pakar Dalam Mendiagnosa Penyakit Menular Pada Anak Dengan Metode Dempster-Shafer. Bina Insani ICT Journal, 3(2), 307-316. Retrieved from http://www.ejournalbinainsani.ac.id/index.php/BIICT/article/vie $\mathrm{w} / 835$

Pormes, R., \& Manongga, D. H. F. (2017). Pemanfaatan Metode Clustering untuk melihat pola penjualan dan perilaku pembelian konsumen, pada penjualan tiket pesawat PT. Garuda Indonesia, Cabang Batam. Jurnal Teknik Informatika Dan Sistem Informasi, 3(3), 483-493. Retrieved from https://journal.maranatha.edu/index.php/ju tisi/article/view/690

PT. PELNI. (2019). Laporan Transaksi Penjualan Tiket Kapal Penumpang. Jakarta.

Putria, N. E. (2018). Data Mining Penjualan Tiket Pesawat Menggunakan Algoritma Apriori Pada Terminal Tiket Batam Tour \& Travel. Computer Based Information System Journal, 6(1), 29-39. Retrieved from http://ejournal.upbatam.ac.id/index.php/cbi s/article/view/643

Rezkiani. (2016). Implementasi Data Mining Dengan Algoritma Apriori Untuk Menentukan Merek Sepatu Yang Diminati Pada Mahasiswa Pascasarjana Kelas 14.1a.01 Stmik Nusa Mandiri jakarta. KNIT-2 Nusa Mandiri, 2(1), INF.49-INF.56. Retrieved from https://konferensi.nusamandiri.ac.id/prosidi ng/index.php/knit/article/view/45

Siregar, S. R. (2014). Implementasi Data Mining Pada Penjualan Tiket Pesawat Menggunakan Algoritma Apriori( Studi Kasus: Jumbo Travel Medan ). Pelita Informatika Budi Darma, 7(1), 152-156. Retrieved from https://docplayer.info/82011-Implementasidata-mining-pada-penjualan-tiket-pesawatmenggunakan-algoritma-apriori-studi-kasusjumbo-travel-medan.html

Surmayanti, Marfalino, H., \& Rahmi, A. (2015). Penerapan Analysis Clustering Pada Penjualan Komputer Dengan Perancanganan Aplikasi Data Mining Menggunakan Algoritma K-Means ( Study Kasus Toko Tri Buana Komputer Kota Solok ). In Prosiding Senatkom (Vol. 1, pp. 50-59). Retrieved from http://lppm.upiyptk.ac.id/senatkom/index.p $\mathrm{hp} /$ senatkom/article/view/7 
Yakun, Y. \&. (2018). Data Mining Untuk Analisis Pola Pemilihan Menu Pada Penang Corner Cafe Dan Resto Menggunakan Algoritma Apriori. J-SISKO TECH, 1(2), 114-123. Retrieved from https://ojs.trigunadharma.ac.id/index.php/js $\mathrm{k} /$ article/view/37 